\title{
Cultural Heritage of Turkic-Speaking Peoples in World Collections: Historical Audio Recordings of The Berlin Phonogram Archive
}

Fatima Nurlybayeva

Kazakh National University of Fine Arts, neris060607@mail.ru

\begin{abstract}
In the countries of the Turkic world, for more than 100 years of using sound recording devices, a huge amount of various sound materials on the traditional musical art of the Turkic peoples have been accumulated, recorded by scientists from different countries, in different regions and on different media. The first historical sound recordings of the Turkic-speaking peoples, which are of significant historical, cultural and scientific value, are kept separately in various foreign archives and have not received a complete and comprehensive study. This article provides a brief presentation of the unique historical audio materials of the music of the Turkic-speaking peoples, which were collected by German scholars at the beginning of the 20th century and are stored in the Berlin Phonogram Archive.
\end{abstract}

\section{Keywords:}

Historical audio recordings of Turkic-speaking peoples, Berlin phonogram archive, musical heritage of Turkic-speaking peoples

\section{Recommended Citation}

Nurlybayeva, F. (2021). Cultural Heritage of Turkic-Speaking Peoples in World Collections: Historical Audio Recordings of The Berlin Phonogram Archive. Eurasian Music Science Journal. Tashkent, Uzbekistan, (2), pp. 54-66.

DOI: $10.52847 /$ EAMSJ/vol_2021_issue_2/70.

This Article is brought to you for free and open access. It has been accepted for inclusion in Eurasian music science journal (www.eamsj.uz). 


\section{Introduction}

In this article, we will briefly present an overview of the various archival materials and information about the audio collections of music of Turkic-speaking peoples, made by German scientists and stored in the funds of the Berlin Phonogram Archive. The materials were prepared by the author during a scientific trip to the Berlin Phonogram Archive, October 2019, within the framework of a scientific project of the International Organization of Turkic Culture TURKSOY.

The countries of the Turkic world have a huge amount of diverse sound materials on the traditional musical art of the Turkic-speaking peoples, recorded by scientists from various countries, in various regions. Historical sound recordings of the Turkic-speaking peoples, recorded at the beginning of the XX century on wax cylinders, are of significant historical, cultural and scientific value, they are stored separately in various foreign archives and have not yet received a complete and comprehensive study. A significant part of the historical records of the Turkicspeaking peoples, presented in different collections, are stored in the Berlin Phonogram Archive.

\section{Berlin Phonogram Archive}

The Berlin Phonogram Archive (Berliner Phonogramm-Archive) was founded in 1900 on the initiative of the psychologist Carl Stumpf and originally belonged to the Psychological Institute of the University of Berlin. Then, under the leadership of Erich Moritz von Hornbostel, it became one of the leading sound repositories of its time. In 1934 the Berlin Phonogram Archive was transferred to the Museum of Ethnography (Museum für Völkerkunde). During World War II, the collections of the archive were separated, some of them ended up in Leningrad, from where they were returned in the late 1950s. to East Berlin, to the Academy of Sciences. In 1991, the collections were reunited in the Ethnological Museum 
2021 Number $22021 / 2$

19-12-2021

(Völkerkundemuseum Berlin-Dahlem), where now they are part of the Department of Ethnomusicology. It contains more than 150,000 records, mainly samples of traditional music from more than 230 nations of the world, including more than 30,000 wax rolls (originals, copper negatives and wax copies having the status of originals). The archive's historical collections also include 2,000 shellac records [1,2]. In 1999, the Berlin Phonogram Archive, one of the largest sound archives in the world, was included in the UNESCO "Memory of the World" List [3]. Since December 2020, the funds of the Berlin Phonograms Archive and the Sound Archive (Berliner Lautarchiv) of the Humboldt Institute have been merged to the Unified Fund.

From the very first years of the Vienna and Berlin Phonogram Archives, its researchers regularly conducted "classical" phonographic research, traveling to various regions of Europe, Africa, Asia, America and Australia to collect and record folklore of different peoples. For example, Adolf Dirr studied the Caucasus and Transcaucasia (1903-1909) [4, 5]; Richard Karutz made research expeditions to Central Asia and Kazakhstan in 1905-1907 [6]; Felix von Luschan - Turkey, Syria 1902, Albert von Le Coq - Turkestan 1904 [7], Erich M. von Hornbostel - Pawnee Indians 1906, Theodor Koch-Grünberg - Brasilia 1912, etc.

The Turkic-language collections of the Berlin Phonogram archive are unique and priceless, as they are the first recorded audio materials, the rarest sound documents on the history of culture and music of the Turkic-speaking peoples. Along with the later recordings of the Turkic-speaking peoples, made in the second half of the 20th century and at the beginning of the 21 st century, there are historical records recorded in the period from the early 1900s to the 1920s that are widely represented in the funds of the Berlin Phonogram Archive. Historical audio materials of the Turkic-speaking peoples from the funds of the Berlin Phonogram Archive, made by researchers in different years, can be conventionally divided into several groups: 
1. The first group is represented by the Historical records of the Turkicspeaking peoples made by ethnographers at the beginning of the twentieth century during expeditions and fieldwork in regions that are inaccessible to European researchers - Central Asia and Kazakhstan, East Turkestan, the Caucasus and Transcaucasia, Turkey. Since the early 1900s, specialists from the Vienna and Berlin Phonogram Archives began to intensively conduct ethnographic research in Central Asia, Kazakhstan, the Caucasus, the Caspian region - they recorded traditional musical folklore, published books and articles based on the results of their research, lectured on language, culture and traditional music. First of all, this is due to the materials of such researchers as Richard Karutz, Adolf Dirr, Albert von Le Coq and others.

\section{Richard Karutz}

Richard Karutz (1867-1845) - German doctor, anthropologist and ethnologist belonged to the generation of founders of ethnographic museums in Germany, such as Karl Wehle (Leipzig), Georg Tilenius (Hamburg), Willy Foy (Cologne), Lucien Shermann (Munich) or Augustin Kraemer (Stuttgart / Tübingen) [6]. R. Karutz was the founder and director of the Völkerkundemuseum in Lübeck from 1896 to 1921. The researcher made a number of ethnographic expeditions to West Africa, South America, Central Asia, Turkestan, Caucasus, Spain, France, England, Holland, Belgium, Italy, Denmark, Sweden, Russia. He is the author of numerous studies and articles on ethnology and anthroposophy [6].

In 1903, 1905 and 1909, Richard Karutz went on research expeditions to Mangistau and Turkestan three times, after which he described in detail the life, customs, economy, games, ornamental art in the book "Among the Kirghiz and Turkmens in Mangyshlak". During these expeditions R.Karutz made recordings of folklore samples, both song and instrumental, on a phonograph. Sound materials on 16 wax discs recorded by him on a phonograph during these years are stored in the 
Berlin Phonogram Archive, and today they are the very first historical audio recordings of the traditional music of the Turkic peoples. Some samples were notated and published in the Supplement to the German edition of the book by R. Karutz "Among the Kirghiz and Turkmens in Mangyshlak" (1910).

In 2018, the Turkestan collection of songs and instrumental pieces compiled by R. Karutz (1905) was published in Kazakhstan. It includes songs and instrumental pieces of Kazakhs, Tatars and Uzbeks, recorded by German scientists at the beginning of the last century in Kazalinsk and Tashkent cities. A team of scientists from Tatarstan, Uzbekistan, Kazakhstan and Russia, under the leadership of S. Utegalieva, a professor of the Kurmangazy Kazakh National Conservatory, carried out complex work on the restoration of poetic texts, on the notation of songs and instrumental pieces. In total, 13 records were notated, including 6 Kazakh songs and kuis, 5 Tatar songs and 2 Uzbek instrumental pieces. There are lyrical, religious, erotic songs, wonderful Tatar takmaks, as well as dance pieces for the Uzbek gidjak. The collection is published in three languages (Kazakh, Russian and English)[7]. The "Turkestan collection of songs and instrumental pieces" collected by R. Karutz is of historical importance, since these samples are the first audio materials, historical sources of the music of the Turkic peoples of Central Asia, the scientist recorded those samples that were popular in this region at the beginning of the 20th century.

\section{Adolf Dirr}

Adolf Dirr (1867-1930) - German linguist, specialist in Caucasian languages, Honorary Doctor of the University of Munich (1908), Director of the Museum of Ethnology (Munich, 1913). The researcher collected very interesting material during his several fieldwork in the Caucasus between 1900 and 1913. He first visited Tbilisi in 1900 and then traveled through the Caucasus until 1902. In 1903 and 1904 he visited Azerbaijan and Central Dagestan (North Caucasus), between 1904 and 1910 


\section{9-12-2021}

- Tusheti (East Georgian mountain province), Chechnya, Dagestan, Tbilisi, Svaneti (mountain province in north-western Georgia), between 1911 and 1913 - Abkhazia (a province of Georgia with autonomous rights) and Ossetia, then Kartli, Imereti, Kakheti (Georgian provinces), which he already knew quite well. While working in the Caucasus, Dirr also paid attention to the collection of ethnographic materials (including artifacts), and also made photographs and phonographic records. Sound materials on 38 wax discs, recorded by him on a phonograph in 1909 in Zagataly, Baku, Tbilisi, Dagestan, are stored in the Vienna Phonogram Archive. From 1910 to 1913 Adolf Dirr made more than 30 recordings of folk music of Laz, Mingrelian, Svans, Abkhaz and Ossetians, which are in the Museum of Ethnography in Berlin.

Records from A. Dirr's collection, stored in the Vienna Phonogram Archive, include unique samples of audio speech and folklore of Baku Tatars, Talysh, Azerbaijani Lezghins and Avars, and are of great interest for science, as the earliest recorded audio materials of the Turkic-speaking peoples of the Caucasus [8]. Due to the fact that, at the moment, after technical restoration and careful scientific editing by specialists of the Vienna Phonogram Archive, the complete collection of historical records by Adolf Dirr has already been prepared for publication, more detailed information on these historical records can be made only after the publication of the project.

2. The second group of historical sources is represented by audio recordings of Turkic-speaking prisoners-of-war of the First World War of 1915-1918. 


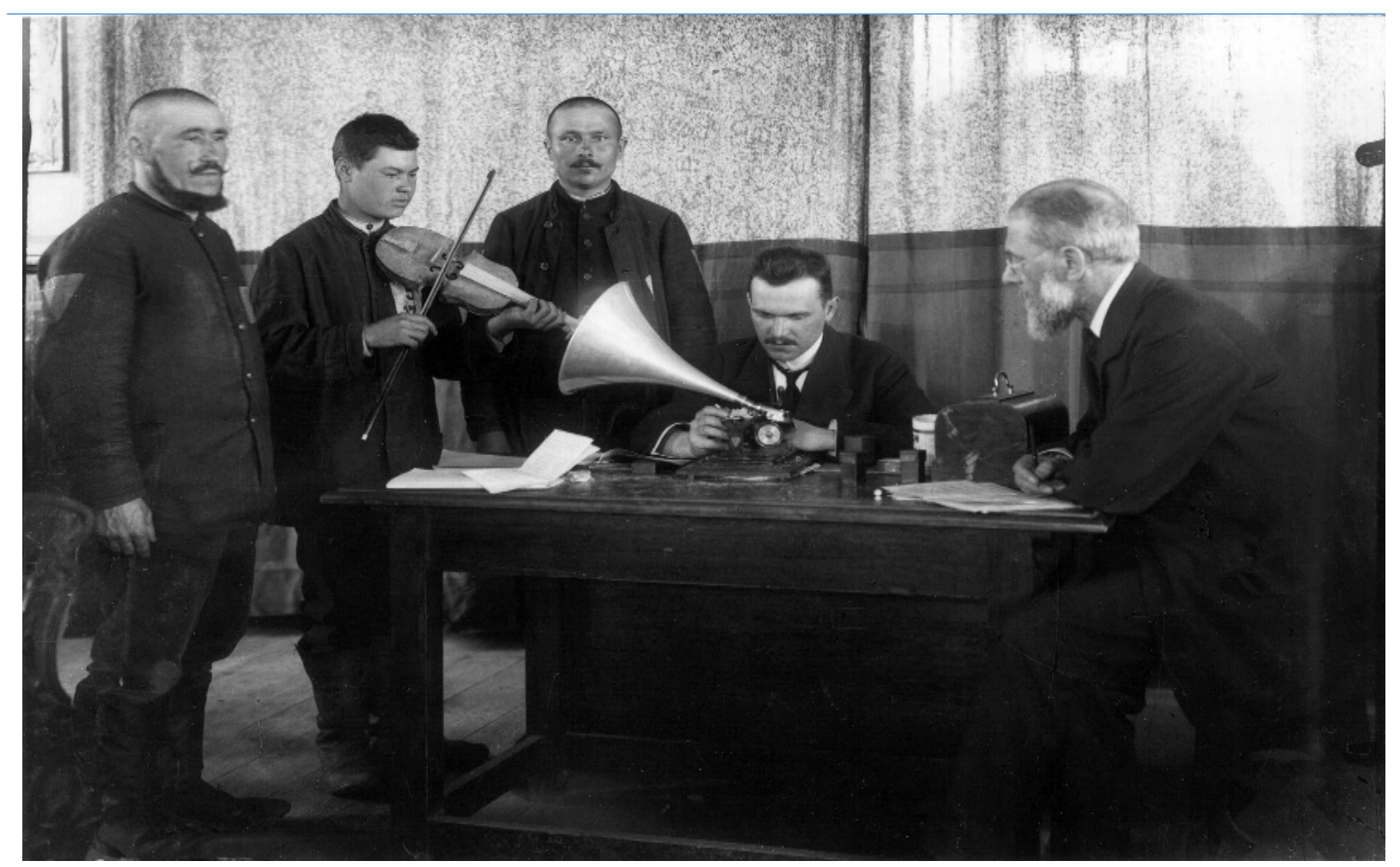

Pic. 1. C. Stumpf (first from the right) and G. Schünemann (in the centre) recording Tatar musicians in Frankfurt/Oder, 1915.

An important part of the collection of the Berlin Phonograms Archive consists of recordings of the song folklore of prisoners-of-war, which during the First World War were conducted by a group of researchers led by Professor K. Stumpf and at the initiative of W. Dögen, the future founder of the Berlin Sound Archive[9]. The First World War created an "unprecedented opportunity" for the recording of vast linguistic and musical samples of "almost all peoples of European and Asian Russia" $[10,11]$, in POW camps, which imprisoned more than 2.5 million soldiers in Germany, 1.3 million in camps in the territory of the Austro-Hungarian Empire. The Commission on Musical Recordings was headed by K. Stumpf; A. Hornbostel, who in 1905 took over as director of the Phonograms Archive, only briefly participated in the work [12]; responsible for the recordings in the POW camps, beginning in March 1916, was his graduate student Georg Schünemann, who made more than 1,000 recordings in 25 POW camps. 
While the musicologists of the Stumpf Phonographic Commission worked with Edison's phonograph, orientalists and linguists used the gramophone and signed a contract with the record company Odeon, which took over the production and subsequent packaging of the recordings. The first recordings at a POW camp took place in Deberitz near Berlin on December 29, 1915. [12]. Between late 1915 and late 1918, Commission staff visited a total of 31 German POW camps [13], where linguistic and musicological research was carried out. This resulted in a total of 1651 gramophone recordings with voice, musical and instrumental recordings, as well as 1022 wax cylinders with music recordings $[13,14,15]$. The received historical audio recordings of prisoners-of-war are still stored in the Phonogram Archive, they became part of a large-scale scientific project of the Anthropological Society,that is carried out with the support of the Ministry of Science, Arts and Education of Prussia [16,17]. In accordance with the plan of this scientific project, the researchers highlighted three main ethnic categories of Russian prisoners-of-war, which are of interest to them: 1. "Finno-Ugric" peoples, Komi, Udmurts, Mari, Chuvashes and Mordvins; 2. ethnic groups who speak Turkic languages, including Bashkirs and Volga and Crimean Tatars; 3. peoples of the Caucasus region [14].

Among the more than 200 different ethnic groups that have been registered in Germanic prison camps, the language and music of the Turkic-speaking peoples represent an important part of the research. Samples of song and instrumental folklore of the Turkic-speaking peoples were recorded on wax discs and accompanied by an appropriate protocol was applied to each of them [17]. The phonographic records of the Turkic-speaking ethnic group, made by K. Stumpf and G. Schönemann, represented Bashkirs, Kumyks, Tatars, Chuvashes. According to the results of the recordings in the POW camps, there have been preserved detailed descriptions of recording procedures from G. Schönemann's musicological remarks and hypotheses $[18,19]$. 


\section{Summary}

Thus, the work on the analysis of the Historical records of the Turkicspeaking peoples of the Berlin Phonograms Archive it is possible to draw the following conclusions:

1. The first Historical sound recordings of the Turkic-speaking peoples, recorded on wax cylinders and magnetic tapes, are unique and invaluable historical sound documents on the history of the language, culture and music of the Turkic-speaking peoples, which have no analogues in the sound archives of the Turkic countries.

2. These audio materials have become part of the UNESCO "Memory of the World" Programme and represent tremendous potential as sources for contemporary research in linguistics, ethnography and ethnomusicology. For the introduction of these historical materials into the international scientific turnover, it is necessary to carry out comprehensive scientific research on the Turkic-language collections and publish these audio collections with the protocols and commentaries of specialists.

\section{Acknowledgments}

I would like to express my deepest appreciation to the Curator of Berlin Phonogram Archive Albrecht Wiedmann and Prof., Dr. Lars-Christian Koch for helpful advice and unwavering guidance during the research. Special thanks to the Secretary General of the International Organization of Turkic Culture TURKSOY Dusen Kasseinov for invaluable contribution and support. 


\section{References:}

[1] Mehnert, D. (1996). Historische Schallaufnahmen-Das Lautarchiv an der Humboldt-Universität Berlin [Historical sound recordings - The sound archive at the Humboldt University of Berlin]. Studientexte Zur Sprachkommunikation. Elektronische Sprachsignalverarbeitung. 13, pp. 28-45. Berlin: Bayer, Kirsten and Mahrenholz, Jürgen.

[2] Ziegler, S. (2010). Dieakustischen Sammlungen - Historische Tondokumente im Phonogramm-Archiv und im Lautarchiv [The acoustic collections - historical sound documents in the phonogram archive and in the sound archive]. Theater der Natur und Kunst (Essays) [Theater of nature and art (essays)]. Edited by Horst Bredekamp, Jochen Brüning and Cornelia Weber. Berlin: Henschel, pp. 197-206. [3] Retrieved from https://en.unesco.org/programme/mow.

[4] Kowar, H. (2017). Die Anlage einer Art phonographischen Archives - mehr als ein Archiv. Ein Überblick über die Geschichte des Phonogrammarchivs der Österreichischen Akademie der Wissenschaften [The creation of a kind of phonographic archive - more than an archive. An overview of the history of the phonogram archive of the Austrian Academy of Sciences]. Geistes, sozial und kulturwissenschaftlicher Anzeiger [Spiritual, social and cultural scoreboard]. 152. Jg., Booklet 1, pp. 5-45. Wien: Verlag der Österreichischen Akademie der Wissenschaften [Publishing house of the Austrian Academy of Sciences].

[5] Graf, W. (1964). Aus der Geschichte des Phonogrammarchivs der Österreichischen Akademie der Wissenschaften [From the history of the phonogram archive of the Austrian Academy of Sciences]. Bulletin Phonographique [Phonographic Bulletin]. 6, pp. 9-39. Wien.

[6] Templin, B. (2010). O Mensch, erkenne Dich selbst - Richard Karutz (18671945) und sein Beitrag zur Ethnologie [O man, know yourself - Richard Karutz (1867-1945) and his contribution to ethnology]. Lübecker Beiträge Zur Ethnologie [Lübeck Contributions to Ethnology]. p. 380. Lübeck: Schmidt-Römhild Verlag. 
[7] von Le Coq, A. (1928). Barwell, Anna, (trans., ed.). Buried treasures of Chinese Turkestan: an account of the activities and adventures of the Second and Third German Turfan Expeditions. p. 190. London: George Allen \& Unwin (Repr:1985, OUP. ISBN 0-19-583878-5).

[8] Utegalieva, S. (2018). Collection of Audio Records of R. Karutz. Turkestan Collection of Songs and instrumental pieces, collected by R. Karutz (1905). pp. 5663. Almaty: Asyl Kitap Publ.

[9] Dirr, A. (1928). Einführung in das Studium der kaukasischen Sprachen. Mit einer Sprachenkarte [Introduction to the study of the Caucasian languages. With a language card]. p. 80.

[10] Doegen, W. (1925). Unter fremden Völkern: Eine Neue Völkerkunde [Among Foreign Peoples: A New Ethnology]. pp. 9-17. Berlin.

[11] Pöch, R. (1916). Phonographische Aufnahmen in den k.u.k. Kriegsgefangenenlagern (=41. Mitteilung der Phonogramm-Archivs-Kommission der Kaiserlichen Akademie der Wissenschaften in Wien). [Phonographic recordings in the k.u.k. POW camps (41st communication from the phonogram archive commission of the Imperial Academy of Sciences in Vienna)]. Wien.

[12] Lechleitner, G. (2020). Rudolf Pöchs technisch- methodische Pionierleistung im Dienste der Ethnographie. [Rudolf Pöch's technical and methodological pioneering work in the service of ethnography]. Acham, Karl (Hrsg.), Die Soziologie und ihre Nachbardisziplinen im Habsburgerreich. Ein Kompendium internationaler Forschungen zu den Kulturwissenschaften in Zentraleuropa [A compendium of international research on cultural studies in Central Europe]. pp. 728-730. Wien/Köln/Weimar: Böhlau.

[13] Ziegler, S. (2006). Die Wachszylinder des Berliner Phonogramm-Archivs. Veröffentlichungen des Ethnologischen Museums Berlin [The wax cylinders of the Berlin Phonogram Archive. Publications of the Ethnological Museum Berlin]. n. F. 
73. Photographs, bibliographical references, discography, appendices, indexes, CD recording. Berlin: Staatliche Museen zu Berlin.

[14] Mahrenholz, J.-K. (2012). The Lautarchiv of the Humboldt-Universität zu Berlin [The sound archive of the Humboldt-Universität zu Berlin]. Jan Ross (ed.). Encapsulated Voices: Estonian Sound Recordings from the German Prisonerof-war Camps 1916-1918. pp. 14-26. Vienna: Böhlau.

[15] Mehnert, D. (1996). Historische Schallaufnahmen - Das Lautarchiv an der Humboldt-Universität Berlin. [Historical sound recordings - the sound archive at the Humboldt University of Berlin]. Studientexte zur Sprachkommunikation. Elektronische Sprachsignalverarbeitung [Study texts on language communication. Electronic speech signal processing]. 13, pp. 28-45. Dresden: TUDpress.

[16] Scheer, M. (2010). Captive Voices: Phonographic Recordings in the German and Austrian Prisoner-of-War Camps of World War I. Reinhard Johler, Christian Marchetti, Monique Scheer (eds.) Doing Anthropology in Wartime and War Zones. pp. 279-311. ISBN 978-3-8394-1422-4.

[17] Lange, B. (2013). Die Wiener Forschungen an Kriegsgefangenen 1915-1918. Anthropologische und ethnographische Verfahren im Lager [The Vienna Research on Prisoners of War 1915-1918. Anthropological and ethnographic processes in the camp. Wien: Verlag der Österreichischen Akademie der Wissenschaften. (Österreichische Akademie der Wissenschaften, Philosophisch-Historische Klasse, Sitzungsberichte, 838; Veröffentlichungen zur Sozialanthropologie, 17). ISBN 9783-7001-7084-6.

[18] Schünemann, G. (1923). Das Lied der deutschen Kolonisten in Russlandmit 434 in deutschen Kriegsgefangenenlagern gesammelten Liedern (Sammelbände für vergleichende Musikwissenschaft 3) [The song of the German colonists in Russia - with 434 songs collected in German prisoner-of-war camps (anthologies for comparative musicology 3]. Münich. 
[19] Schünemann, G. (1919). Über die Beziehungen der vergleichenden Musikwissenschaft zur Musikgeschichte [On the Relationship of Comparative Musicology to Music History]. Archiv für Musikwissenschaft 2 [Musicology Archives], no. 2 (1919/20), pp.175-194. 